\title{
Euphemisms of Corruption among Students of Higher Institutions in South West Nigeria
}

\author{
Olumuyiwa K. Ojo, Olusola Ayandele, Sunday A. Egbeleye \\ The Polytechnic, Ibadan
}

\begin{abstract}
Correspondence concerning this article should be addressed to Olumuyiwa K. Ojo, The Polytechnic,
\end{abstract} Ibadan, Sango-Eleyele Road, Ibadan, 200284, Nigeria.E-mail: olumuyiwak.ojo@polyibadan.edu.ng

\begin{abstract}
Corruption is a pervasive practice in Nigeria that is commonly associated with government officials who divert public funds for private use, while minimal attention is paid to acts of corruption in the educational sector. This study, which is part of research on how language is used to drive and conceal corruption in Nigeria, aims at revealing some corrupt practices in Nigerian higher institutions that are concealed because of the euphemistic language used by students to describe and help perpetuate corrupt practices in their relationships with academic and non-academic staff of different institutions. Four institutions of higher education in south-west Nigeria were purposively selected and focus group discussions were conducted with 54 conveniently selected students of these institutions to collect qualitative data on the explanation of linguistic codes derived from the first phase of this study. The findings revealed extensive usage of 'runs' as a superordinate code for diverse acts of corruption including: sex for marks, cash for marks, sex/cash for grade alterations, examination malpractice, and the use of fake documents. Parents and guardians need to listen closely to the language of students in higher education for early detection of assimilation and acceptance of corrupt practices as a way of life.
\end{abstract}

Keywords: runs, euphemism, corruption, academic fraud, coded language

\section{Introduction}

Corruption is a global social malady that distorts the established order of society by conferring undeserved benefits on individuals or groups. Transparency International (2007, p.15) defines corruption as "the abuse of entrusted power - by a public official or a businessperson for example - for private gain". It classifies corruption into different categories as grand and petty, based on the amount of money lost and the sector involved. Grand corruption, according to this global watchdog on corruption, refers to corrupt practices perpetrated by highranking government officials to alter policies or functioning of the state. Petty corruption refers to the daily abuse of delegated power by low- and mid-level public officials in charge of providing access to basic amenities such as schools, healthcare services, security, and other services to the citizens.

Corruption in higher education refers to a "lack of academic integrity" (Denisova-Schmidt, 2017, p.1). Osipian (2009) defines corruption in education as a system of all informal relations aimed at regulating "unsanctioned access to material and nonmaterial assets." Academic corruption is described as all wrong doings and dishonest acts perpetrated within colleges and higher institutions of learning by institutional administrators, lecturers or teachers, students, and other stakeholders in the academic sector that have negative consequence on the standard of education and the academic goals of the institutions (Adebisi, Adebisi, \& Arogundade, 2012). Chapman and Lindner (2016) opined that academic corruption is a threat to the integrity of certificates obtained from the educational sector; this unethical practice is harmful and capable of destroying the very purpose of education. Corruption has escalated in Nigeria and its practices extend to the university system (Okojie, 2012 as cited in Uche, 2014).

The concept of corruption is usually learnt from others through the process of socialization. Learning the culture of corruption cannot be discussed only in terms of language since language is only one of the major instruments 
of communicating and transmitting culture; thus the risk of transmitting the culture of corruption via linguistic resources to the younger generation becomes inevitable (Dumbili \& Sofadekan, 2016). Language is a human system of communication that uses arbitrary signals, such as speech sounds, gestures, or written symbols. Since it is primarily used in the transfer of meaning (messages) in the process of communication, language cannot be separated from the culture of the people using it, the period of its usage, and the environment of its usage. Bloch and Trager (1942, p. 2) describe language as "a system of arbitrary vocal symbols by means of which a social group cooperates." Thus, the lexicon of a language can give significant insight into the philosophy and values of the people who use the language. It is in this context that the euphemisms employed by students in descriptions of corruption become useful for understanding Nigerian students' attitude towards corruption. Devitt and Sterelny (1987) as cited in Adetugbo (1997, p. 6) define language as "a uniquely powerful communication system that is stimulus-and-medium-independent, abstract, arbitrary and productive." The productive and arbitrary characteristics of language allow users to creatively invent new words to refer to ideas, thoughts, and behaviour. It allows users to invent euphemisms for ideas that others may find offensive.

Euphemism is a figure of speech that cleverly hides the truth of its reference and is designed to avoid confrontation, hurting people's feelings, or as a substitute for profanity (Rittenburg, Gladney, \& Stephenson, 2016). They are usually used to make a sensitive, unpleasant, or offensive event, behaviour, or language more acceptable to the listener (Chi \& Hao, 2013). Euphemisms are coined to also enable corrupt people to pass across their messages tactfully by obfuscating the real meaning of what is being said and rendering it incomprehensible to non-users of the code so much so that a person who is not familiar with the code will face difficulties grasping what is being said (Meutem Kamtchueng, 2017). In the context of describing or referring to corrupt practices, euphemisms are used to make the behavior more acceptable to the casual listener and the society at large in many countries across the world. Corruption and corrupt acts by public servants are labeled as Chorizo, 'sausage' in Costa Rica and across Central America; Coima, 'gifts', in Argentina; Fakelaki, 'envelope', in Greece; and Kula, 'eating', in Tanzania; while euphemisms for a bribe in Italy is Bustarella, 'little envelope'; Hongbao, 'envelope', in China; Mordida, 'to bite', in Mexico; and Magharich', 'gift-giving', in Armenia as described in the Global Encyclopedia of Informality (Ledeneva, 2018).

Corruption has been euphemized in the indigenous languages spoken by Nigerians in their daily transactions, the Igbos call it Igbuozu, the Yorubas call it Egunje, and the Hausas call it Chuachua ${ }^{1}$. The language used in the business of corruption has been a source of interest to different scholars. In Nigeria, Agbedo (2012); Bassey and Bassey (2014), Adegoju and Raheem (2015), Dumbili and Sofadekan (2016) and other researchers have examined how corruption thrives on the wings of some ingeniously crafted words to suit the goals of perpetrators in given settings. Baez-Camargo and Ledeneva (2016) revealed that members of the elite used stomach infrastructure to allow ordinary citizens access to scarce basic amenities in order for the ruling class to maintain their grip on power so as to use government funds and facilities to achieve personal goals. Adegoju (2007) identifies the debasement of Nigeria's value system as a reason for the creative use of words when engaging in corruption. Aribisala (2014) pointed to how ex-president Goodluck Jonathan employed euphemisms to argue that "what many Nigerians refer to as corruption is actually stealing, stealing is not the same thing as corruption"2. Bangura (2007) uses metaphorical language to discuss corruption in Sierra Leone, while Desta (2016) studies euphemisms for corruption in Ethiopia. Safotso (2015) and Meutem Kamtchueng $(2015,2017)$ researched the language of corruption in Cameroon.

According to Denisova-Schmidt (2017) corruption in the higher education sector takes various forms, whether monetary or nonmonetary, and might range from bribery and funds misappropriation to fake degrees, plagiarism, ghostwriting, and cheating. Students in Nigeria have conceptualized absenteeism, armed robbery, boycotts of lectures, bribery, cheating, cultism, lecturers dating students, dereliction, destruction of property, educational malpractice, electoral malpractice, embezzlement, examination malpractice, extortion, favouritism, fighting, forgery, fraud, gangsterism, immorality, impersonation, intimidation, lateness, littering, lying, materialism, misappropriation, murder, plagiarism, prostitution, rape, rioting, robbery, the sale of (school) property, seduction, sexual harassment, sorting (inducement), smuggling, stealing, theft, unruly behaviour, vandalism, and victimization as corrupt behaviours (Idoniboye-Obu, 2014). These acts of corruption were covered up by students with the use of euphemisms that may exclude the uninitiated (Ojo, Egbeleye, \& Ayandele, 2017).

\footnotetext{
Ndokwu, J.N (2004, May 26). Corruption, corrupt practices and Honest leadership in Nigeria. http://www.corruption.newscorrupt.org/ printer

2 Aribisala, F. (2014). Nigerian politicians are thieves, but they are not corrupt. Vanguard Newspaper, 2014. Retrieved from http://www. vanguardngr.com/2014/ 07/nigerian-politicians-thieves-corrupt/
} 
Runs (used in the plural form), for example, is an euphemism used by students to refer to different subversions of established rules and regulations during a student's stay on a campus of a higher institution in Nigeria, from admission to graduation (Ojo et al., 2017). It is a general term for all corrupt practices done in collusion with other corrupt members of the academic community in which such students operate: non-academic staff, lecturers, business centre operators, students, etc. Although run exists as a verb in the English language, its euphemistic usage has a completely different meaning. Runs in this sentence for example: "Let me do some runs about the coming examination." means to make some illegitimate plans/arrangements that will enable the speaker to pass the coming examination without studying. Runs is therefore a euphemism that cleverly hides a plethora of borderline illegal and immoral activities among students at higher institutions in Nigeria. Our search for literature that link runs with corrupt practices on Nigerian campuses did not yield much fruit. Scholars like Ojebode, Togunde, and Adelakun (2010) see it as a one-off sexual encounter with an older man; they defined runs as an ultra-casual encounter with sex often taking place in a house, hotel room, nightclub, or even in a car, with the partners knowing nothing or little about each other. Ekundayo (2013) discovers the entrenchment of runs among educated Nigerians to denote shady deals, socio-economic activities, sexual engagement, etc. done within certain time limit and some level of privacy. A runs girl means a girl into sex for quick money while a runs guy is a guy involved in illicit activities. Similarly, Okorie and Bamidele (2016) identify a runs girl as a euphemism for the term prostitute. Some young people engage in runs because they either do not know that it is wrong, refuse to accept it is wrong, or could not understand why it is wrong (Okoli, 1997).

An appropriate theoretical framework for this study is the Sapir-Whorf hypothesis of linguistic relativity. Linguistic relativity as a strand of the Sapir-Whorf Hypothesis proposes that language influences how we think, the way we perceive and remember, and generally, it predisposes us to conceptualize the world in a certain way (Penn, 1972). There is a two-way influence between 'the kind of language we use' and 'the way we see the world'. The hypothesis places emphasis on the social context of language use rather than strictly linguistic considerations, such as the social pressure in particular contexts to use language in one way rather than another (Chandler, 1994, as cited in Adegoju, 2007). Hill and Mannheim (1992) and Thierry (2016) agree that one's language can connect and influence one's thought and one's world view.

The current study collected qualitative data on the variant usage of runs, which is the dominant linguistic code for corruption derived from students' responses in a previous study by Ojo et al (2017). This current study is a follow-up to their study, which used a sample of 200 undergraduate students in Nigeria and found most of the respondents to be highly knowledgeable about the various euphemisms used for corruption in Nigeria (Ojo et al., 2017). The respondents identified runs as an umbrella term for the daily abuse of entrusted power in the academic environment by low- and mid-level officials (academic and non-academic) in their interactions with students. In this paper, we seek to understand the forms of runs, provide additional explanations for the other euphemisms of corrupt practices that runs denotes in the Nigerian academic context, and recommend possible ways of curbing this ugly trend.

\section{Method}

\section{General Background}

A cross-sectional descriptive study was conducted among undergraduates of four purposively selected public higher institutions in two cities in Oyo State, Nigeria: (a) one federal university; (b) one state polytechnic; (c) one federal college of education; and (d) one state college of education. The study respondents were representatives of Nigerian students, particularly those in south-west Nigeria. Locating our study in this part of Nigeria was purely a matter of convenience, rather than an attempt to suggest that runs was more prevalent there than elsewhere within or outside Nigeria.

\section{Participants}

The respondents were sampled according to gender, level, and type of institution (Appendix A). There were twenty-eight (52\%) male students and twenty-six (48\%) female students among the respondents. Eight (15\%) students were in 100 level/National Diploma 1/Year 1, thirteen (24\%) were in 200 level/ National Diploma 2/ 
Year 2, nineteen (35\%) were in 300 level/ Higher National Diploma 1/Year 3, while fourteen (26\%) were in 400 level/ Higher National Diploma 2 classes. Fifteen (28\%) of the respondents were students in state polytechnic while the federal university had thirteen (24\%), the federal college of education thirteen (24\%), and the state college of education thirteen $(24 \%)$ respondents.

\section{Materials}

Data collection using the qualitative technique of Focus Group Discussions (FGDs) was employed to elicit reliable responses from the respondents and this took two months (March-April 2018). The focus group discussions was aided by the use of an FGD guide (Appendix B), which contains the topic of discussion and the respondent's sex, level, and name of institution. Some of the questions discussed were: "What is corruption? What is runs?" and probing respondents for corrupt practices like bribery, examination malpractices, and other types of runs they had experienced in school.

\section{Procedure}

Two focus group discussions were conducted in each of the four selected schools, in the evenings, at locations where students usually congregate to relax.

The researchers introduced themselves to the students and explained the purpose of the study. The consent of students was sought prior to their participation and their privacy was guaranteed to the extent that information would never be traced to these respondents. Each FGD session started with a brief introduction of the members and the topic of discussion, followed by ground rules and a discussion of the questions (Appendix B). They lasted a minimum of 50 minutes, with respondents ranging from five to eight (in all, 52 respondents engaged in the FGDs). The FGD guide contained questions relating to the corrupt practices that runs is used to represent. Respondents were asked to conceptualize runs, mention its euphemistic meanings, and explain how students use those euphemisms when describing corrupt practices on their campuses. Later, the researchers summarized the main points for respondents to make comments on or ask questions about. The researchers applied ethical guidelines as specified by the Department of Psychology, University of Ibadan, Nigeria, obtained consent from the respondents, and ensured that their responses were treated confidentially and used purely for academic research.

\section{Data Analysis}

The audio recordings of the FGDs were transcribed, and we employed constant comparison analysis (Leech \& Onwuegbuzie, 2008) for coding and grouping the responses by paying attention to terms, contexts, meanings, and examples used by respondents. Responses in Yoruba (a Nigerian indigenous language) and Nigerian Pidgin English are retained in their original forms for authenticity although they were translated to English during data analysis for communicative purposes.

\section{Results}

Responses during the focus group discussions showed that corrupt practices described as runs on campuses can be categorized into four categories, namely:

1. Trading sex for marks (having sex with or providing other women to have sex with lecturers/school officials)

2. Examination malpractice

3. Bribing school officials with money for marks or changes of grades

4. Using fake documents (results/certificate) for admission/clearance.

The literal and contextual meaning of the euphemisms for each category of runs is discussed below. 


\section{Trading Sex for Marks}

Table 1a reveals the prevalence of sexual immorality or corruption of established standards in the institutions of higher learning. Nine euphemistic terms are used to describe various shades of exchanges of sexual satisfaction for marks or alteration of grades.

Table 1a

Trading Sex for Marks

\begin{tabular}{|c|c|c|}
\hline Euphemism & Literal Meaning & Contextual Meaning \\
\hline Fifty/fifty & $\begin{array}{l}\text { A sharing arrangement where both parties } \\
\text { shared the items equally. }\end{array}$ & $\begin{array}{l}\text { An arrangement where a female student engages in sex } \\
\text { with a male lecturer for marks. }\end{array}$ \\
\hline Praise and Worship & $\begin{array}{l}\text { This is a part of Christian liturgy where } \\
\text { worshippers praise God with music of different } \\
\text { kinds. }\end{array}$ & $\begin{array}{l}\text { A situation where a female student sets out to satisfy a } \\
\text { male lecturer in a sexual act. }\end{array}$ \\
\hline Trade by barter & $\begin{array}{l}\text { A system of trade where an item is exchanged for } \\
\text { another item having equal value. }\end{array}$ & $\begin{array}{l}\text { This is used to depict the act of offering sex to a lecturer in } \\
\text { exchange for marks. }\end{array}$ \\
\hline Settle in kind & $\begin{array}{l}\text { This is ordinarily used to mean giving someone a } \\
\text { moral support instead of cash /money }\end{array}$ & $\begin{array}{l}\text { A situation where a female student offers her body to a } \\
\text { lecturer as settlement to obtain marks. }\end{array}$ \\
\hline Farase (Verb) & $\begin{array}{l}\text { A Yoruba expression for manually engaging in a } \\
\text { task one could have paid others to do. }\end{array}$ & $\begin{array}{l}\text { This is when a female student offers her body to a lecturer } \\
\text { to obtain marks. }\end{array}$ \\
\hline Control + Shift + Delete & $\begin{array}{l}\text { A computer keyboard command to restart a } \\
\text { system. }\end{array}$ & $\begin{array}{l}\text { This refers to an operation originating from a student who } \\
\text { arranges a female student for a willing lecturer who in turn } \\
\text { changes the poor examination mark of the organiser. }\end{array}$ \\
\hline Bait (Noun) & $\begin{array}{l}\text { Any food item used in catching fish or other } \\
\text { animals by attracting them to a hook or net }\end{array}$ & $\begin{array}{l}\text { An arrangement where a student organizes a female } \\
\text { student who fits the specifications of a lecturer in exchange } \\
\text { for marks. }\end{array}$ \\
\hline Swap (Verb) & An exchange of two comparable things & $\begin{array}{l}\text { This is when a male student releases his girlfriend to a male } \\
\text { lecturer for sexual intercourse in exchange for marks. }\end{array}$ \\
\hline Gbomofun (Verb) & $\begin{array}{l}\text { This is a Yoruba word which means give the baby } \\
\text { to someone }\end{array}$ & $\begin{array}{l}\text { Omo is used here to mean babe/girl/lady. This is a situation } \\
\text { where a student arranges a girl for a lecturer in order to } \\
\text { get marks. }\end{array}$ \\
\hline
\end{tabular}

\section{Examination Malpractice}

Table $1 \mathrm{~b}$ reveals the euphemistic terms used for different acts of examination malpractice. Six such terms were identified and explained in the table. They reveal the extent to which corrupt students will go in order to cheat during examinations. The innovative terms are designed to shift attention away from the negative connotation of fraud to a more linguistically neutral or positive meaning.

Table $1 \mathrm{~b}$

Examinational Practices

\begin{tabular}{|c|c|c|}
\hline Euphemism & Literal Meaning & Contextual Meaning \\
\hline Panpa (Noun) & $\begin{array}{l}\text { Yoruba word for a kind of charmed amulet } \\
\text { used by traditional African hunters and kept } \\
\text { hidden in parts of the body where it could be } \\
\text { easily retrieved when needed }\end{array}$ & $\begin{array}{l}\text { An already prepared material consisting of answers to likely } \\
\text { examination questions hidden in part of the student's body when } \\
\text { going into examination hall }\end{array}$ \\
\hline Follow-come (Noun) & $\begin{array}{l}\text { A Nigerian Pidgin expression for original } \\
\text { components of an item from the manufacturer. }\end{array}$ & $\begin{array}{l}\text { Pages of textbooks or other publications smuggled into } \\
\text { examination halls by student }\end{array}$ \\
\hline Expo (Noun) & $\begin{array}{l}\text { From the root of the word 'exposition'; to } \\
\text { unveil an item. }\end{array}$ & A leaked examination question. \\
\hline Siwasile (Noun) & $\begin{array}{l}\text { A Yoruba compound word expressing a } \\
\text { request to be set free. }\end{array}$ & $\begin{array}{l}\text { A coded request to invigilators to accept gratification in exchange } \\
\text { for creating a free atmosphere for cheating. }\end{array}$ \\
\hline Tattoo (Noun) & Ornamental decoration on human body. & $\begin{array}{l}\text { Writing likely examination answers on any part of the body, } \\
\text { especially on the lap to be used during the examination. }\end{array}$ \\
\hline Formation (Noun) & $\begin{array}{l}\text { Arrangement of human beings in a specific } \\
\text { order to archive a predetermined objective. }\end{array}$ & $\begin{array}{l}\text { A preplanned sitting arrangement that would allow cooperative } \\
\text { exchange of materials or ideas by students during examination. }\end{array}$ \\
\hline
\end{tabular}




\section{Bribing School Officials with Money for Marks or Changes of Grades}

Table 1c reveals the euphemisms for bribery among students. Six such terms were identified and explained. They refer to offering cash to school officials for marks and the alteration of grades. The euphemisms are suggestive of their meanings.

Table 1c

Bribing School Officials with Money for Marks or Change of Grades

\begin{tabular}{|c|c|c|}
\hline Euphemism & Literal Meaning & Contextual Meaning \\
\hline Sort (Verb) & To fix a problem or to handle a task. & $\begin{array}{l}\text { Giving money to a lecturer to pass an examination or a } \\
\text { failed course. }\end{array}$ \\
\hline Subscribe (Verb) & To pay for provision of a service, such as internet access. & $\begin{array}{l}\text { Money given to a lecturer so as to be among those that will } \\
\text { be favoured or get a good grade. }\end{array}$ \\
\hline Followup (Noun) & To follow through an action to ensure its success. & Lobbying a lecturer to change marks scored by a candidate \\
\hline Short-cut (Noun) & A shorter route to get to a destination. & $\begin{array}{l}\text { This is used to mean paying a lecturer to escape taking } \\
\text { part in assignments and class tests while still passing the } \\
\text { course with good grades. }\end{array}$ \\
\hline Upgrade (Verb) & $\begin{array}{l}\text { To improve the quality or performance of an equipment } \\
\text { or machine. }\end{array}$ & $\begin{array}{l}\text { This refers to the payment made by students to data clerks } \\
\text { to alter the original CGPA points of students to a better } \\
\text { one. }\end{array}$ \\
\hline Aja 4 gbera & $\begin{array}{l}\text { This is slang used in virtual games to encourage race } \\
\text { dogs by patrons. It was popularized in the song of a } \\
\text { Nigerian hip-hop artist. }\end{array}$ & $\begin{array}{l}\text { This is when a student pays money to change the level/ } \\
\text { status of his or her CGPA. }\end{array}$ \\
\hline
\end{tabular}

\section{Using Fake Documents}

Table 1d reveals the euphemisms used by students for the use of fake documents. Four such terms were identified. These show the variety of forged documents that students use for gaining admission to institutions and sustaining their studentship.

\section{Comparison of Responses Based on Institution, Gender, Age, and Level}

The responses of the students in the federal university show that they were more conversant with euphemisms "runs" dealing with examination malpractice and trading sex for marks compared to those from the polytechnic and colleges of education whose students extensively discussed the four categories of "runs". Similarly, female respondents spoke more about trading sex for marks and examination malpractice as the types of "runs" they were aware of, while the majority of the male respondents were familiar with the four categories of "runs". Older students and those in higher classes were more exposed to these euphemisms of corrupt practices than students who were younger and in lower classes.

Table 1d

Using Fake Documents

\begin{tabular}{lll}
\hline \multicolumn{1}{c}{ Euphemism } & \multicolumn{1}{c}{ Literal Meaning } & \multicolumn{1}{c}{ Contextual Meaning } \\
\hline Scam & A fraudulent act or deal & $\begin{array}{l}\text { The act of using fraudulent means to get admission or do } \\
\text { registration. }\end{array}$ \\
Ike & $\begin{array}{l}\text { This is a Yoruba world for plastic but often used as } \\
\text { slang for credit/debit cards. }\end{array}$ & $\begin{array}{l}\text { This refers to using fake result to process and gain admission } \\
\text { into higher institutions. }\end{array}$ \\
Fk & $\begin{array}{l}\text { This is an abbreviation of the word fake used by } \\
\text { certain people engaging in fraud or corruption. }\end{array}$ & This means using fake documents to gain admission. \\
Ro'dan & $\begin{array}{l}\text { A Yoruba expression which depicts getting } \\
\text { something done in a somewhat magical manner. }\end{array}$ & $\begin{array}{l}\text { This refers to using fraudulent or corrupt means to achieve } \\
\text { a purpose }\end{array}$ \\
\hline
\end{tabular}




\section{Discussion}

\section{Trading Sex for Marks}

The euphemisms under this category are drawn from various registers like business (fifty/fifty, trade by barter), religion (praise and worship, bait), computer technology (swap, control+shift+delete), Yoruba popular culture (gbomofun, farase). They describe various acts of immoral sexual relationship between students and school officials. Nine such terms were identified and the context of usage is explained in Table 1a. Studies have revealed that sex has become a frequent feature of relationships between male lecturers and female students in Nigeria (Fayankinnu, 2004; Ezumoh, 2004). Fifty/fifty, praise and worship, trade by barter, settle in kind and farase are runs by female students who exchange sex for marks, which support Erinosho's (2004) notion that sex is being traded for marks in some Nigerian higher institutions. Okeke (2011) reveals that some lecturers request sex from students in exchange for marks or make sexual gratification a condition to get good grades. This is illustrated in a recent case involving a professor at Obafemi Awolowo University and a student. The professor allegedly gave the female students two options: have sex with him five times in exchange for upgrading her grades to a pass mark or fail the class ${ }^{3}$. A BBC Africa Eye undercover documentary on "sex for grades" captured four lectures blackmailing female students for sex in exchange for marks and admission at two universities in Nigeria and Ghana ${ }^{4}$. Similarly, Nwaopara, Ifebhor, and Ohiwerei (2008) revealed that sexual harassment of female students by their male lecturers is rampant in different institutions and many lecturers ignore the global condemnation of such practices. Ojebode, Togunde, and Adelakun (2010) revealed that some ladies engage in strategic relationships to further their academic pursuits. Likewise, Okwu (2006) explained that some female students use their sexual prowess to pass their examinations.

\section{Examination Malpractice}

Six euphemistic terms were identified in this category. They all relate to corrupt practices by students in the context of examination halls. The terms are drawn from different registers like technology (follow-come, expo), Yoruba popular culture (siwasile, pampa), make-up (tattoos), and sport (formation). The purpose of this usage is to deceive invigilators, escape scrutiny, and avoid detection. Copied notes, textbooks, and lecture materials smuggled into examination halls known as "panpa", "follow-come", "expo", and "tattoos" are used as aids during examinations. Unauthorized materials smuggled into examination halls by students at educational institutions in European countries are similarly euphemized as "crib sheets" or "ponies" by English speakers, spickzettel by German speakers, and shpargalka or shpora by Russian speakers (DenisovaSchmidt, 2017). Their use by students demonstrates a lack of preparation, a fear of failure, and the admission of unqualified candidates (Ruwa, 1997, as cited in Kawugana \& Woyopwa, 2017). "Siwasile" and "formation" describe a strategy for students to sit in positions that will allow weak students to copy from brilliant ones with the connivance of crooked invigilators while avoiding detection by incorruptible proctors. Students in corrupt education systems don't acquire the skills and knowledge that would enable them to impact their society meaningfully. They learn from a young age that a lack of integrity is an acceptable way of life ${ }^{5}$.

\section{Bribing Officials with Money for Marks or Change of Grades}

Six terms were identified in this category. They describe various acts of corruption perpetuated by students in connivance with academic and non-academic staff. The terms are traceable to the following registers: business (sort, follow-up, subscribe), transportation (shortcut), technology (upgrade), and gambling (aja 4 gbera). Sorts, settle, follow up, peace offering, and short-cut represent bribing with money for marks. Okoye (2006) argued some lecturers are engrossed with the businesses of selling marks in their offices. "Upgrade" and "aja 4 gbera" point to the involvement of both academic and non-academic teaching staff in charge of results processing. Examination officials engage in the deliberate alteration of a candidate's original marks for a fee (Eze 2012; and Olanipekun, 2013, as cited in Oko \& Adie, 2016). Female students without the financial capacity to pay for grades may engage in prostitution to raise funds while larceny and similar vices are perpetuated by male students desperate to raise money to pay for marks (Adewale, 2014; Uzochukwu, 2015, as cited in Oko \& Adie, 2016).

\footnotetext{
3 Adebayo, B., \& Busari, S. (2018, May 23). Lecturer demanded sex in return for better grades, Nigerian student says. CNN International+. http://edition.cnn.com/2018/05/23/africa/sex-for-grades-university-nigeria-intl

4 Mordi, K. (2019, October 7). Sex for Grade: undercover inside Nigerian and Ghanaian universities - BBC African Eye Documentary. Retrieved from https://www.bbc.com/news/av/world-africa-49907376/sex-for-grades-undercovers-in-west-african-universities

5 Transparency International. (2007). Report on the Transparency International Global Corruption Barometer 2007. Transparency International.
} 


\section{Using Fake Documents}

Four terms were identified in this category. They represent euphemisms for different types of fake documents. Ike, is the euphemism for all fake documents ranging from certificates, receipts for payments, or tuition fees. It is derived from the word for plastic, which could have the extended meaning of an inferior material. $F K$ is a phonemic abbreviation of the word "fake". Ro'dan is a Yoruba word whose roots can be traced to the acts of deceptive magic. "Scam" is a direct word for fraudulent acts. Some business centre operators, lecturers, and nonteaching staff are involved in the forgery of documents, admissions fraud, and certificate racketeering (Kanno, 2004). Trushin (2015), cited in Denisova-Schmidt (2017), reported the existence of a black market for fake diplomas in Russia. A former vice-chancellor of the University of Port Harcourt disclosed that "many students

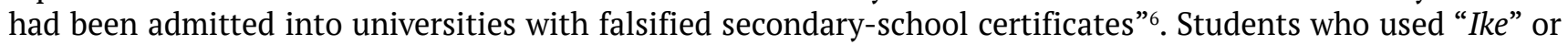
" $F k$ ", or who are involved in "Ro'dan" and "Scam", are building their life on a falsehood that could result in failure in their chosen career if/when they are caught. Tallylo (2006) reported that many students were dismissed from the University of Lagos because of certificate scandals.

\section{Conclusion}

Given that a number of illegal behaviors are collectively referred to as corruption, the findings regarding the existence of different euphemisms for runs is a new addition to the literature on corruption and euphemisms describing corruption. Understanding other euphemisms for runs provides insight into the operations, acts, and motivation for corruption among Nigerian students. This should have implications for the war against corruption, theorizing academic corruption, and intervention strategies. This study is limited by the use of a small number of respondents and the obtained results are only representative of the conveniently sampled individuals in the focus group. They authors recommend that research on academic corruption continue to uncover new forms of corruption and suggest replications with larger samples and with participants from different areas of Nigeria.

Students and parents should clearly define and understand every act of corruption in the academic environment. Higher education institutions should introduce codes of conduct for students and staff, and adopt whistleblowing mechanisms to encourage the reporting of academic corruption without fear of victimization. The Nigerian society should consciously shift its attention away from mere certification to competence in order to encourage students to seek knowledge rather than employ fraudulent means to obtain unmerited certification. Reported cases of corruption should be investigated and the perpetrators prosecuted. The use of runs in the educational system is a monster that threatens the state of education and the credibility of certificates awarded in Nigeria.

\section{Conflict of Interest}

The authors declare that they have no conflict of interest.

\section{References}

Adebisi, P. A., Adebisi, O. S., \& Arogundade, K. K. (2012). Academic corruption and the challenge of unemployable graduates in Nigeria: Implications for entrepreneursh ip development and economic growth. Journal of Commerce, 1(4), 1 - 12.

Adegoju, A. (2007). Corruption of language and Nigeria's debased value system. Nebula, 4(3), 339-356.

Adegoju, A., \& Raheem, S. O. (2015). Gone are the days of 'kola(nut)': New trends in language habits and coding of corrupt practices in Nigeria. Journal of Language and Literature, 26, 155-171.

Adetugo, A. (1997). English phonetics: A course text. University of Lagos Press.

Agbedo, C.U. (2012). 'Verbal carpentry' as language of political corruption in Nigeria. OSR Journal of Humanities and Social Science, 6(2), 27-36. http://doi.org/10.9790/0837-0622736

Alutu, O. E., \& Alutu, A. N. G. (2003). Examination malpractice among undergraduates in a Nigerian University: Implications for academic advising. Guidance and Counselling Journal, 18(4), 149-152.

Baez-Camargo, C., Ledeneva, A. (2016). Where does informality stop and corruption begin? Informal governance

\footnotetext{
${ }^{6}$ Kigotho, W. (2004, November 1). Nigerian University revokes thousands of diplomas in crackdown on academic fraud. The Chronicle of Higher Education. Retrieved from http://www.utexas.edu/conferences/africa/ads/19.html
} 
and public/private crossover in Mexico, Russia and Tanzania. The Slavonic and East European Review , 95(1), 49-75. http://doi.org/10.5699/slaveasteurorev2.95.1.0049..

Bangura, A. K. (2007). Understanding and fighting corruption in Sierra Leone: A metaphorical linguistic approach. Journal of Third World Studies, 24(1), 59-72.

Bassey, E., \& Bassey, V. (2014). Language of corruption and anticorruption in Nigeria. Journal of Contemporary Research, 11(2), 45-59.

Bloch, B., \& Trager, G.L. (1942). Outline of linguistic analysis. Linguistic Society of America.

Chapman, D. W., \& Lindner, S. (2016). Degrees of integrity: The threat of corruption in higher education. Studies in Higher Education, 41(2), 247-268. https://doi.org/10.1080/03075079.2014.927854

Chi, R., \& Hao, U. (2013). Euphemism from sociolinguist tics perspective. Studies in Sociology of Science, 4(4), 4548. http://dx.doi.org/10.3968/3898

Denisova-Schmidt, E. (2017). The Challenges of Academic Integrity in Higher Education: Current Trends and Prospects. CIHE Perspectives, 5. The Boston College Center for International Higher Education.

Desta, H. H. (2016). Euphemism for corruption in Ethiopia. http://aigaforum.com/article2016/Euphemism_for_ Corruption_in_Ethiopia_Desta_Haileselassie_Hagos.pdf

Dumbili, E.W., \& Sofadekan, A. (2016). “I Collected Money, not a Bribe”: Strategic ambiguity and the dynamics of corruption in contemporary Nigeria. Social Science, 5(3), 36-42. http://dx.doi.org/10.3390/socsci5030036

Ekundayo, S.B. (2013). Lexico-semantic 'intraference' in educated Nigerian English (ENE). International Journal of English Linguistics, 3(6), 17-30. http://dx.doi.org/10.5539/ijel.v3n6p17

Erinosho, L. (2004). Challenges in higher education in Nigeria. The Nigerian Social Scientist, 7(2), 31-38.

Ezumah, N. (2004). Understanding sexual harassment in institutions of higher learning in Nigeria. The Nigerian Social Scientist, 7(2),19-23.

Fayankinnu, E. A. (2004). Ethics and sexual harassment in staff / students relations: Who harasses who? The Nigerian Social Scientist, 7(2), 13-18.

Hill, J. H., \& Mannheim B. (1992). Language and world view. Annual Review of Anthropology, 21, 381-406. http:// psycnet.apa.org/doi/10.1146/annurev.an.21.100192.002121

Idoniboye-Obu, S.A. (2014). Corruption in higher education in Nigeria: Prevalence, structures and patterns among students of higher education institutions in Nigeria [Unpublished doctoral dissertation]. University of KwaZulu-Natal.

Kanno, T. N. (2004). Changing values in Nigerian society and curriculum implications. In B. B. Oderinde \& O. Ekpo (Eds.), Values education (pp. 12-17). Nigerian Academy of Education

Kawugana, A., \& Woyopwa, A. K. (2017). Impact of exam malpractice on the quality of graduates in Nigeria. International Journal of Education and Evaluation, 3(6), 45-51.

Ledeneva, A. (Ed.). (2018). The global encyclopaedia of informality: Understanding social and cultural complexity (Vol. 2). UCL Press. https://doi.org/10.14324/111.9781787351899

Leech, N. L., \& Onwuegbuzie, A. J. (2007). An array of qualitative of qualitative data analysis tools: A call for qualitative data analysis triangulation. School Psychology Quarterly, 22, 557-584.

MeutemKamtchueng, L. M. (2015). C'estçaqueje mange? / Is that what I eat? - Examining the language of corruption in Cameroon. International Journal of Language Studies, 10(1), 125-148.

Meutem Kamtchueng, L. M. (2017). Give an envelope for the boss / Give a brown envelope for the boss - On the semantics and characteristics of the metaphors for bribe across cultures: Focus on Cameroon and Nigeria. Journal of Language \& Education, 3(1), 45-57. https://doi.org/10.17323/2411-7390-2017-3-1-45-57

Nwaopara, A., Ifebhor, A., \& Ohiwerei, F. (2008). Proliferating illiteracy in universities: A Nigerian perspective. International Journal for Educational Integrity, 4(1), 31-42.

Ojebode, A., Togunde, D., \& Adelakun, A. (2010). Beyond money and gifts: Social capital as motivation for crossgenerational dating among tertiary school female students in south west Nigeria. The International Journal of Interdisciplinary Social Sciences, 4,169-182. https://doi.org/10.18848/1833-1882/CGP/v05i04/51673

Ojo, O.K., Egbeleye, S.A., \& Ayandele, O. (2017). A psycholinguistic analysis of the euphemism of corruption in Nigeria. Paper presented at the 2017 National Conference of the Faculty of Business and Communication Studies, The Polytechnic, Ibadan, Nigeria.

Okeke, C.M.A. (2011). Impact of sexual harassment on women undergraduates' educational experience in Anambra state of Nigeria [Unpublished doctoral dissertation]. Seton Hall University.

Oko, S. U., \& Adie, R.I. (2016). Examination malpractice: Causes, effects and possible ways of curbing the menace. A study of Cross River University of Technology. International Journal of Managerial Studies and Research, 4(1), 59-65. http://dx.doi.org/10.20431/2349-0349.0401006

Okoli, C.E. (1997). Examination malpractice, the bone of our society. In A. Ejiogu \& K. Alani (Eds.), Emergent 


\section{EUPHEMISMS OF CORRUPTION AMONG STUDENTS OF HIGHER INSTITUTIONS}

Issues in Nigeria Education (pp. 343-348). Unilag Consult Publication.

Okorie, M. M., \& Bamidele, O. (2016). Language and class resistance in Nigeria: A foucauldian perspective. Africology: The Journal of Pan African Studies, 9(6), 4-15.

Okoye, R. O. (2006). Special examination centers: Their activities and measures for controlling them. NISEP publications.

Okwu, O. J. (2006). A critique of students' vices and the effect on quality of graduates of Nigeria tertiary institutions. Journal of Social Science, 12(3), 193-198.

Penn, J. M. (1972). Linguistic relativity versus innate ideas: The origins of the Sapir Whorf hypothesis in German thought. Mouton.

Rittenburg, T. L., Gladney, G. A., \& Stephenson, T. (2016).The effects of euphemism usage in business contexts. Journal of Business Ethics, 137(2), 315-320. https://doi.org/10.1007/s10551-014-2501-4

Safotso, T. G. (2015). The metalanguage of corruption in Cameroon-part I: The registers of general administration, transport and education. International Journal of English Linguistics, 5(2), 47-54.

Tallylo, N. L. (2006). Ghost voice malpractice. Third Eye Publication.

Uche, R. D. (2014). Students' perception of corrupt practices among Nigerian universities lecturers. American Journal of Humanities and Social Sciences, 2(1), 66-69. https://doi.org/10.11634/232907811402511 


\section{Appendix A}

100 level refers the first year of undergraduate studies in the university. 200 level refers to the second year of undergraduate studies in the university. 300 level refers to the third year of undergraduate studies in the university. 400 level refers to the fourth year of undergraduate studies in the university. Universities award Bachelor degrees after four to six years of post-secondary studies.

National Diploma 1 (ND I) refers to the first year of national diploma studies in the polytechnic. National Diploma 2 "(ND II) refers to the second year of national diploma studies in the polytechnic. Higher National Diploma 1 (HND I) refers to the first year of higher national diploma studies in the polytechnic. Higher National Diploma 2 (HND II) refers to the second year of higher national diploma studies in the polytechnic. Polytechnics award National Diploma after two years of post-secondary studies and Higher National Diploma is awarded after two years of post-national diploma studies.

National Certificate of Education (NCE) Year 1 refers to the first year of national certificate of education studies in the college of education. National Certificate of Education (NCE) Year 2 refers to the second year of national certificate of education studies in the college of education. National Certificate of Education (NCE) Year 3 refers to the third year of national certificate of education studies in the college of education. Colleges of education train teachers for primary and secondary schools and award National Certificate of Education after three years of post-secondary studies.

Federal institutions of learning are owned by the Federal Government of Nigeria while state institutions are owned by state governments.

\section{Appendix B}

\section{Focus Group Discussion (FGD) Guide}

Introduction: (Name of Moderator, note taker, topic and modality of conducting the FDGs)

Sex: Male [ ] $\quad$ Female [ ]

Level:

Name of Institution:

Topic: Euphemisms of Corruption among Students of Higher Institutions in Southwest Nigeria

\section{Questions:}

1. What is corruption?

2. What is runs?

3. Probe for types of runs

4. Probe for names (euphemisms) given to runs by students

5. Probe for runs relating to sexual activities for marks

6. Probe what runs is used for bribing officials for marks

7. Probe for runs that takes place before, during and after examinations

8. Probe for runs during the admission, clearance and graduation process

9. Ask respondents any other question as you round off discussion. 